


\section{Water as an}

Urban Resource and

Nuisance

By Harold E. Thomas and William J. Schneider

WATER IN THE URBAN ENVIRONMENT

GEOLOGICAL SURVEY CIRCULAR 60I-D

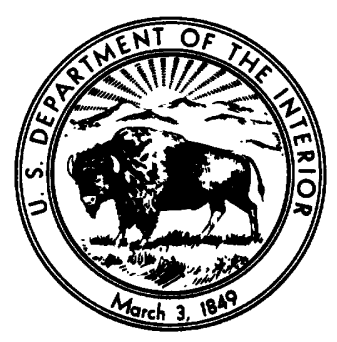




\section{United States Department of the Interior}

THOMAS S. KLEPPE, Secretary

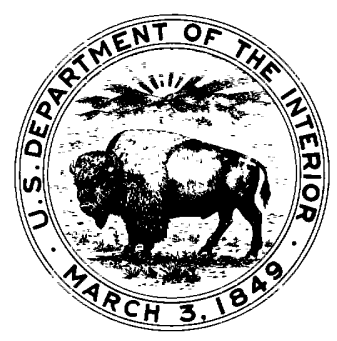

\section{Geological Survey}

V. E. McKelvey, Director 


\section{FOREWORD}

Urbanization-the concentration of people in urban areas and the consequent expansion of these areas-is a characteristic of our time. It has brought with it a host of new or aggravated problems that often make new demands on our natural resources and our physical environment. Problems involving water as a vital resource and a powerful environmental agent are among the most critical. These problems include the maintenance of both the quantity and quality of our water supply for consumption, for recreation, and general welfare and the alleviation of hazards caused by floods, drainage, erosion, and sedimentation.

A prerequisite to anticipating, recognizing, and coping intelligently with these problems is an adequate base of information. This series of reports is intended to show the relevance of water facts to water problems of urban areas and to examine the adequacy of the existing base of water information.

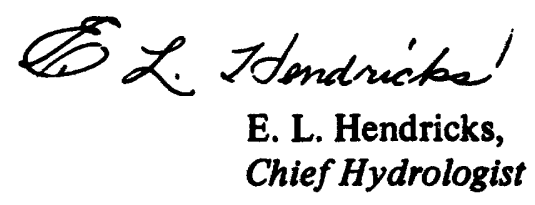





\section{CONTENTS}

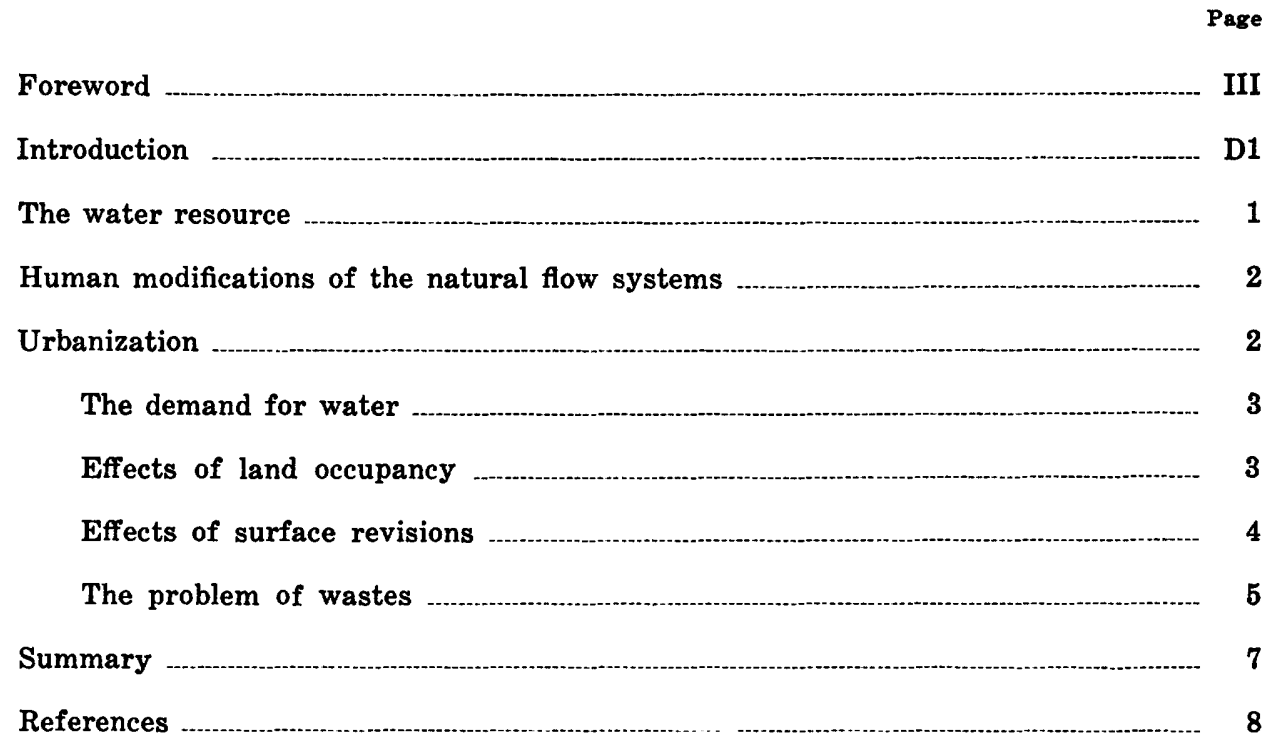





\title{
Water as an Urban Resource and Nuisance
}

\author{
By Harold E. Thomas and William J. Schneider
}

\section{INTRODUCTION}

Generally, when people speak ot water as a resource, they are considering its good aspects and recognizing that it is essential for life and living. Sometimes or at some places or to some people, the same water may be annoying or unpleasant and thus a nuisance-for example, rain at a picnic, snow at any time except Christmas Eve, ground water in a basement, floodwater inundating personal property, and any water after it has been polluted by somebody else.

For purposes' of this circular, water as a resource will be defined more broadly and as a nuisance more narrowly. Water is part of the natural resource base including all aspects of the land, the air, and the water that must be considered in planning if an environment suitable for the well-being of all life is to be maintained. A nuisance, private or public, is a cause of annoyance, inconvenience, or injury that is an invasion or disturbance of the rights of some particular person or of members of a community, and it is punishable under the laws or customs accepted by the community. An activity harmful to mankind but widely practiced by the general public may be condoned by human laws and thus not be defined legally as a nuisance; the punishment for this activity is deterioration of the natural environment until it becomes unsuitable for living.

The water resource, which is widely and irregularly distributed on earth, is available to man for such enjoyment and development and use as he sees fit, some use being essential to his existence. Natural variations in the quantity and quality of water are inevitable and, if they cause annoyance or injury to someone, are accepted as one of the hardships that this planet imposes upon its inhabitants; such variations are recognized as "acts of God." However, if any man or society is partly responsible for these variations, which may cause such annoyance or injury, and may become a nuisance (an invasion or disturbance of the rights of others) such a man or society may perhaps be subject to injunctions and damage suits. Legal disputes over water as a nuisance are generall" deeply involved with problems of the respective rights of plaintiff and defendant. These respective rights vary among the States.

\section{THE WATER RESOURCE}

Water is a replenishing resource. T $\bullet$ fresh water on or in the land masses of the earth is replenished by precipitation. The vapor lost from the atmosphere by precipitation is replenished by evaporation of water, partly from the land masses but chiefly from the oceans. The net water loss from the oceans-evaporation from the water surface less precipitation over the oceans-is replenished by runoff from the land masses. This is the hydrologic cycle, simple in principle but complex in procers.

The average annual precipitation over the conterminous United States is equivalent to a layer of water 760 millimeters (30 inches) thick. About 28 percent of this water, equivalent to a layer $220 \mathrm{~mm}$ thick, eventuclly runs off to the oceans, but in the meantime it constitutes the fresh water potentially available for man's continuing uses and enjoyment. The rest of the gross supply returns to th ? atmosphere as water vapor by evaporation from water surfaces and moist land and by transpiration from vegetation, both native and cultivated.

Geographically there is a wide range in average annual precipitation, in evapotransniration, and in the difference between the two. A waterbalance map (Piper, 1965), based on average annual precipitation and potential evapotranspiration, indicates the areas and amounts of surplus and deficiency throughout the conterminous United States. The princiral areas of perennial surplus are the eastern 31 States, the Pacific Northwest, and several high moun- 
tain ranges in the West. Perennial water deficiency is characteristic of most of the western half of the country. In areas of perennial deficiency the natural water economy and human activities respond to the water-scarce environment and rely wherever possible on inflows from areas of perennial surplus, regulation and use of seasonal or occasional local surpluses, and depletion of stock resources of ground water for temporary benefit. In areas of perennial surplus human activities are adapted to the environment of water abundance. The surpluses are needed for various uses and for carrying away wastes and are managed to overcome occasional deficiencies and to protect against damaging floods.

\section{HUMAN MODIFICATIONS OF THE NATURAL FLOW SYSTEMS}

Thanks to the renewability afforded by the hydrologic cycle, water as a resource serves the continuing needs of mankind and other forms of life. Beneficial use of water, essential for urban life, is recognized as a social good. Many types of uses of water either reduce the quantity or impair the quality of the natural resource; such uses may be detrimental to other individuals or to the public. The right to use water, however, is recognized and protected as a property right; so that proving a nuisance involves weighing the merits of the respective rights of all parties involved.

The use of water may require substantial structures or other developments such as dams to provide storage and regulation of the natural flow, canals and pipelines to divert and distribute water to places of use, collecting systems, treatment plants for impure water, wells to yield ground water, pumps to lift water, and channels and dredging to provide navigability. All these are intended to modify the natural flow systems for the benefit of mankind. The degree of benefit may vary among individual water users who are dependent upon the development. In some places or to some people the effects of water development may be detrimental and qualify as nuisances.

The natural flow systems may be modified by human activities concerned primarily with elements of the natural-resource base other than water. The development and use of the land-or, more broadly, of the solid earth or lithosphere-are not primarily concerned with water, but rather are concernec with fossil fuels, the solls for agriculture, metallic and other minerals for manufacturing, rocks and sediments for construction, and the land surface for occupancy. In such development water, not sought as a resource, may be incidental or accidental and even a hazard at some times and places. The use of the land may r?quire drainage of unwanted water or protection from excesses of water during storm and fods. Water may constitute a nuisance if it harms the development and use of the solid-earth resources or otherwise invades recognized property rights. Conversely, the development and use of the land resources may have effects on wrter that interfere with the water rights of others; such interference may also be a nuisance.

\section{URBANIZATION}

"Of all land-use changes affecting the hydrology of an area, urbanization is by far the most forceful" (Leopold, 1968). More than twothirds of the Nation's population is currently in urbanized areas occupying about 7 percent of the land. This clear majority could, under unifying leadership, control the destiny of the urban area and also the 93 percent of the land that is relatively vacant. The total pop lation is increasing; however, the urban population is increasing at a more rapid rate. Thes trends suggest that the urban population in A. D. 2000 will be three-fourths of the total pc nulation and more than the total population totay. The urbanized area will also increase tc perhaps 10 percent of the land area.

The great majority of urban dwellers are not concerned with individual rights and responsibilities in water as a resource. These rights have necessarily been delegated to the community because individual plots of lard are generally too small to provide adequate supply, storage, or disposal of water for its oscupants. On the other hand, each individual is concerned about water as a nuisance. Water may disrupt his well-ordered urban life by accumulating in low spots (such as lands, basements, and underpasses), by making mud in unpaved areas, by eroding ground laid bare by con truction, by carrying debris and filth, and $\mathrm{k} \%$ damaging property during floods. Sometimes individual responsibility for such nuisances can be clear- 
ly identified. However, the natural environment has been modified so thoroughly in many urban areas that the responsibility for specific nuisances may be widely dispersed. For that reason, the community, or the public, has assumed increasing responsibility for the correction of and protection against the detrimental effects of water.

\section{THE DEMAND FOR WATER}

Municipal water supply, including domestic, commercial, and industrial supplies, is at an average daily rate of 600 liters (157 U.S. gallons) per capita throughout the United States. A population of 500,000 thus requires about 100 million cubic meters annually, equivalent to about $70 \mathrm{mgd}$ (million U.S. gallons a day), and there are 35 municipal systems of this size or larger. The demand of the largest municipal systems, in New York City and Chicago, is 15 to 20 times this rate (Durfor and Becker, 1964).

Of the 35 largest cities, five have abundant supplies from the Great Lakes and 10, from major rivers. The others originally depended on wells, springs, or small streams in the vicinity, but with progressively increasing and concentrated demand they have had to reach out beyond the urban area for their supplies. Today only three of these cities-Miami, San Antonio, and Memphis-obtain their entire municipal supply locally from ground water. Houston relied upon wells until its population exceeded half a million and then had to add a supplemental surface supply from Lake Houston. Local sources now provide less than 5 percent of New York City's supply, which comes chiefly from the Croton, Catskill, and Delaware systems of reservoirs as much as 200 kilometers (about 125 miles) from the city. In California the cities of San Francisco, Oakland, and Los Angeles have long pipelines to the Sierra Nevada for municipal water supply. Los Angeles and San Diego also import water from the distant Colorado River. Other large cities rely on streams and impoundments that are less distant but nevertheless beyond their incorporated areas.

Municipal systems meet the water requirements of most commercial and industrial establishments and of the great majority of the people in urban regions. The aggregate withdrawal by these systems, however, is less than one-fifth of the amount withdrawn nationally by "self-supplied" industries. Most of these large industrial users are also in urban areas and may be in competition with municipal systems for the available water resources.

Municipal and industrial uses of water are chiefly nonconsumptive. Thus large qcantities of water can be withdrawn from a river and quickly returned, with little loss in volume and therefore negligible depletion of the flow. However, the used water brings to the river dissolved chemicals, organisms, floating debris, sediment, gases, or heat, which are all pollutants that may be detrimental to other water users downstream.

\section{EFFECTS OF LAND OCCUPANCY}

Buildings, streets, sidewalks, parking lots, and other structures provide an impervious cover on the land surface and thus prevent infiltration into the soil and recharge of gro'nd water. The water from storms is diverted instead into storm sewers. Years ago, when Erooklyn was troubled by seawater encroachment into some of its wells, part of the cause was the reduction of recharge caused by the buildings and pavements that covered about half of the total land surface of the borough (Lusczynsk: 1952).

This urban sprawl, with its quota of impervious cover, commonly extends across natural valleys which, although not occupied b: a perennial stream, would carry storm rur off into stream channels. The natural drainage may be replaced by storm sewers. For example, the suburbanized drainage basin of Rock Creek. tributary to the Potomac River in the Washington metropolitan area, had $102 \mathrm{~km}$ of natural flowing stream channels in 1913 , but only $4 £ \mathrm{~km}$ can be found above ground today (U.S. Department of Interior, 1968).

Storm runoff is substantially modified by the impervious cover and the storm sewers that are introduced by urbanization. Lag time, the time from the peak of rainfall to the peak of runoff, is decreased by the impermeable surfaces and by storm sewers. Leopold (1968) used data from studies of the effects of urbanization in various parts of the United States ard stated that for unsewered areas the differences between 0 and 100 percent impervious cover will increase peak discharge on the average 2.5 
times. For areas that are 100 percent sewered, peak discharge will be about 70 percent greater than the mean annual flood for unsewered areas under conditions of no impervious cover and about eight times greater under conditions of 100-percent impervious cover.

By modifying infiltration rates and storm runoff, urbanization reduces the ground-water recharge and also causes adjustment in the stream channels to accommodate the flows. As channels are enlarged by the increased number and volume of floods, they frequently develop unstable and unvegetated banks and scoured or muddy beds. The low flows may be less than under natural conditions because of reductions in ground-water recharge.

A significant percentage of the Nation's population and tangible property is concentrated on flood-prone areas. A recent survey shows that in New York State 260 , or 79 percent of the 330 communities having populations greater than 2,500 have problems of local flooding or drainage. Much urban growth in the United States is by encroachment upon the flood plains, which are the river's natural freeways for discharge of exceptional floodwaters. Flood damages are a direct consequence of flood-plain infringement, both private and public.

In the United States flood damage in 1967 totaled $\$ 1.7$ billion; practically all this damage was in urban and suburban areas. Perhaps more significant than the dollar value is the fact that, according to the [U.S.] Water Resources Council (1968) flood damage will continue to increase even while we continue our floodcontrol programs and protective measures. Despite past history and future projects, there is continuing pressure to develop flood plains and other lands subject to water and flood hazards.

Evidence that natural catastrophes can be aggravated by land development has recently been provided by southern California. Damage from the catastrophic floods of January and February 1969 was intensified by the urban sprawl (Rantz, 1970). Although record-breaking rainfall was the prime cause of flooding, peak discharges were increased and mud flows were accelerated by the excess water in areas where natural plant cover was destroyed and where slopes were undercut by erosion or grading; such areas include many of the more desirable and expensive real estate developments.

\section{EFFECTS OF SURFACE REVI'IONS}

Preparation of land for use commonly involves clearing, grading or leveling, digging for foundations, and perhaps landsce.ping. During these activities, as Wolman (1964) points out,

Because construction denudes the nat'ral cover and exposes the soil beneath, the tonnage of sediment derived by erosion from an acre of ground under construction in developments and highways may exceed 20,000 to 40,000 times the amount eroded from farms and woodlands in an equivalent period of $t$ :me.

In Fairfax County, Va., 197 acres undergoing highway construction over a 3-yes.r period contributed 37,000 tons of sediment to the local stream (Vice and others, 1969). The highway construction was limited to 11 prcent of the Scott Run basin, but the sediment contributed by this area was 94 percent of the total sediment yield during the 3-year period. In Montgomery County, Md., more than 4,500 tons of soil was eroded during construction of 89 houses on a 20 -acre site during a 5 -year period.

Construction activities commonly cover very small proportions of most urban areas at any one time, and as a rule the rate of sediment yield decreases with increasing drainage area. Nevertheless, Anderson and McCell (1968) report a positive correlation betwean urban development and sediment throughout New Jersey. In the urbanized northeastern part of the State, sediment yield is three to five times greater than in the rural and forested northwestern part. Sediment yield in the vicinity of Trenton and in the urban area adjacent to New York City is many times greater than in rural areas. Also, the increasing average turbidity of the Passaic River, in 1965 more than twice as great as in 1954, reflects increasing urbanization.

During excavations some materials can maintain stable walls until the construstion is completed. Others remain stable as long as they remain dry, but water from rain, orerland flow, or shallow ground water may lubricate clayey elements enough to cause sliding or caving. The instability of walls or steep slopes composed in part of materials that can be lubricated by water has its natural counterpart in areas of landslides or potential landslides. In several places natural landslide areas have been subjected to urban development. Indeed, some of the earliest records concerning landslides are of 
those which occurred within the city of Bath, England, in 1790 and again in the extremely wet year 1799. William "Strata" Smith, called the father of geology in England, achieved considerable fame for his remedial work, which included tunneling into the hillside to intercept ground water. Thorough drainage of the landslide area and development of public gardens has prevented further sliding. Although the land slopes are generally in the range of 12 to 15 degrees, they remain stable as long as they are adequately drained and not overloaded (Kellaway and Taylor, 1968).

Some materials, though unstable when wet, may nevertheless be included in urban development and do not reveal their hazardous character until some triggering geologic event, such as the earthquake at Anchorage on March 27, 1964, where the principal damage was from landslides, ground fracturing, lurching, and shaking. In its recovery from the effects of that earthquake and in future land development for human needs, the Borough of Anchorage is insuring that the planning is based on understanding of the geologic and hydrologic environment (Dobrovolny and Schmoll, 1968).

Many excavations penetrate below the water table, and water is pumped out to permit continuation of activities. As has been seen in many areas of intensive pumping and groundwater depletion, the dewatering of some sediments is accompanied by compaction, resulting in subsidence of the land surface. In the Santa Clara Valley in California, the land since 1934 has subsided more than 3 feet in an area of more than 100 square miles and up to 8 feet in places because of ground-water withdrawal. Damage to wells has exceeded $\$ 2$ million; the cost of levees to prevent flooding from San Francisco Bay has been about $\$ 6$ million.

A common type of excavation near urban areas is for the purpose of obtaining construction materials, whether rock, gravel, sand, or clay. If these excavations penetrate below the water table, water will accumulate to form a pool or pond after the extraction has ceased, and the landowner may be accused by neighbors of maintaining a nuisance-an "attractive nuisance" that lures children to play, wade, and swim dangerously.

Abandoned quarries, pits, strip mines, and spoil banks are among the less desirable land areas for urban development, along with such natural features as steep hills, narrow ravines, and undrained depressions. Adjacency to an urban area may induce the owners to make wholesale rearrangement of these surfaces because of the higher land value that may be anticipated. This rearrangement involves cutting into natural materials at various places and filling at others, with problems of stabilization comparable to and perhaps more difficult than those in highway construction. Some of the problems will be caused by water because of interu uptions or modifications of the natural flow systemchanges in rates of infiltration and overland runoff and changes from the natural crainage and ground-water movement.

Some revisions of the land surface involve development of artificial lakes to enhence the quality of the urban environment and the values of land in the vicinity. These lakes may range from a waterhole on a golf course to a lagoon ir a city park to a lake for boating, fishing, and other recreation in a suburban area. As many people have learned after troy construct swimming pools on their property, these water bodies are a resource if they are properly managed; otherwise, they become nvisances. Artificial lakes become part of the hydrologic flow system and as such are vulnerable to flooding, sedimentation, accumulation of floating debris, fertilizers and other chemicals washed from adjacent lands, septic wastes or other dissolved solids contributed by ground water, and growth of algae or other undesirable oryanisms.

\section{THE PROBLEM OF WASTES}

Each individual must dispose of some. wastes, whether by individual or community effort. The average per capita daily waste load of organic materials from food resources is about 100 grams (a quarter of a pound) in sevage and 400 grams in garbage. To this basic load must be added the waste products of minerals, wood, fiber, and other natural resources after use. This load varies widely from one individual to another because it increases with increasing affluence and capability to depreciate the "old" and purchase the "new." A further load is the byproducts of the materials and energy used in developing, processing, and maintaining the desired products of our natural resources. Inexorably, the total volume of waste proc'ucts in- 
creases with increasing population and economic growth. These wastes are portions of our natural resources that are considered to have no current value. Nevertheless they are among the products, perhaps the grossest products, of our gross national product.

For disposal of his wastes primitive man had the alternatives of burning them, resulting in smoke to be dissipated by the atmosphere and ashes to remain on the ground; placing them underground or on land and perhaps covering them, where they might decompose, remain unchanged, or be added to soil or ground water; or discharging them into stream, lake, or ocean, where liquid and dissolved materials would be mixed with other water and solids would float or sink to the bottom. Modern man has developed only one other alternative; currently he has more than 1,100 individual items circling the globe as satellites. With increasing population, land for disposal of wastes of air and water for dilution are becoming progressively less ; moreover, we have more wastes per capita to dispose of. Because of the concentrations of people, economic production, and wastes for disposal, the problem is most critical in urban areas.

Here we are concerned with water as a resource in which wastes, whether dissolved, floating, or suspended, have nuisance value and often are of sufficient concentration that the water itself is deemed a nuisance. However, water pollution is only one aspect of the overall problem of disposal of urban wastes. As the campaigns for clean water, clean air, and better environmental quality coalesce, the common objective must be to develop technologies for conversion of unwanted materials to wanted materials wherever possible and to dispose of the rest in a form and place in which they will be least detrimental to mankind.

In the early stages of change from rural to urban conditions, septic tanks are usually the principal means of disposal of domestic wastes and continue to operate and increase in number until the suburbanites are numerous enough to finance sewerage systems or until the density of septic tanks is so great that serious pollution problems develop. Sparse data indicate that effluent from septic tanks is cleansed of pathogenic bacteria in unsaturated soil at a rate and effectiveness that depend upon the type of soil.
However, even proper spacing to minimize bacterial pollution does not prevent pollution by dissolved inorganic materials, which may become nutrients to algae and other organisms. A prime example of widespread pollution of shallow ground water is provided by Long Island, N. Y. Septic tank effluents from more than half a million homes have contaminated the shallow aquifer over much of the island. Cc ncentrations as high as $32 \mathrm{mg} / \mathrm{l}$ (milligrams per liter) of synthetic detergents (alkylbenzene ulfonate, or ABS) have been detected (Perlmutter and others, 1964) along with increased concentrations of chloride, nitrates, sulfates, and phosphates.

The disposal of solid wastes, whether by sanitary landfill or unsanitary dump, may also cause pollution of ground water $b_{!}^{r}$ infiltration of rain, snowmelt, or overland flow and leaching of soluble organic or inorganic materials. This is true particularly if the dump is in an abandoned pit or other depression whore some of the waste may be saturated by ground water. Landfills in valley floors may cortribute pollutants to streams in time of floods. Few studies have been made of this problem. Obviously, the kind of pollution will depend upon the composition of the refuse and the conditions of disposal. Organic matter such as garbage, decomposing under anaerobic conditions, produces methane, carbon dioxide, ammonia, and hydrogen sulfide. The carbon dioxide combines readily with the water to form carbonic acid, which in turn increases the power of the water to dissolve mineral matter from the refuse ard from soil or rock minerals. Objectionable amo'unts of iron, excessive hardness, and other undesirable constituents may be present in the leaching water. In leachant water high biochemical oxygen demand has also been measured, indicating high bacterial concentrations in the landfills.

Industrial wastes have contaminated groundwater reservoirs seriously enough in some places to reduce their suitability for use. An example is the Baltimore Harbor area in Maryland, which a century ago had many flowing artesian wells. A shallow aquifer has become contaminated by sulfuric acid and copper sulfate from acid and metal-refining plants. The acid water has corroded the casings of many wells, leaked through them into a doeper aquifer, and also contaminated it locally. Heavy pumping encouraged contaminatior also from 
brackish water in the harbor. Because of the high cost of maintaining wells in the corrosive shallow zone and the deteriorated quality of some of the water, the pumpage from wells was reduced by half between 1940 and 1955 (Otton and others, 1964). Fortunately, the Baltimore municipal supply was adequate and available as a replacement.

Many urban areas are served by sanitary sewer systems and sewage treatment plants which were adequate at the time they were built for the needs of the service areas and a reasonable expansion of population. Commonly this system was combined with the storm-sewer system. The combined system theoretically works out well to the extent that flushing the streets carries the wastes through the treatment plant, although there must be facilities for bypassing the treatment plant during periods of excessive storm runoff. Unfortunately, some of the sanitary sewage then also bypasses treatment. It became evident to many people that adequate pollution control would require separation of the sanitary-sewer system from the storm-sewer system. Further study has brought second thoughts: first, recognition that such separation in many cities at this time would be exceedingly disruptive and costly; second, realization that the storm sewers would not carry pristine waters, but rather all the crud that had been washed from the atmosphere, roofs, pavements, and streets of the area served. Many analyses of runoff from storm sewers in Seattle, Wash. (Sylvester, 1960), showed that the water sometimes contained excessive numbers of coliform bacteria and had other characteristics of pollution.

A proposed solution to the problem of storm runoff is impoundment of excess water during flood runoff, with subsequent release according to the capacity of treatment facilities. Because urban land is at premium prices, cities are beginning to look for space underground. Currently there are two proposals for the Chicago area: one, by the sanitary district, would provide a network of tunnels in the Galena and Platteville Formations, about 200 meters below the surface; another, by the city, would place tunnels in the Niagara Dolomite, less than 100 meters below the surface, and line the tunnels adequately to seal them from usable groundwater reservoirs. The water and wastes tem- porarily stored in these tunnels would be pumped out and treated and then discharged into streams.

Subsurface disposal of industrial wastes by means of deep wells is undertaken in several places, especially in Texas, Louisiana, and Michigan, but also in some other States. If these wastes are toxic, radioactive, or otherrise noxious, safe disposal requires permanent isolation from all usable water resources. Witrout adequate studies of all the geologic, engineering, and chemical parameters at each project, and constant monitoring of the effects of the disposal, underground disposal can cause serious problems. What is considered to be a safe disposal site today may be a scene of exploitive activity in the future.

\section{SUMMARY}

Water, a resource available for the use and enjoyment of mankind, is subject to natural variations both in quantity and quality from time to time and from place to place. Consumptive uses reduce the quantity and nonconsumptive uses may impair the quality of water available for use by others; therefore, various laws and customs define and protect the respeetive rights of individuals in water use. Although water rights are protected as property rights, there is increasing recognition of the rights of the public in the water resource and the responsibilities of water users for maintenarce of satisfactory quality.

Many urban activities are concerned with development and use of the land and its resources other than water; these activities affect the natural water flow system and are affected by it. The development and use of water may create nuisances if they adversely affect the use of the land and solid-earth resource and invade recognized property rights. Conversely, the development and use of the land resources may have effects on water that interfere with the rights of others and thus cause nuisances. Here too there is increasing recognition of human rights to an environment suitable for living, and adverse activities are not to be condoned merely because of widespread practice and acceptance in the past.

In urbanized areas, water as a resource becomes increasingly inadequate to meet the re- 
quirements of the concentrated population and industry; it must be imported from other areas, along with food, fuel, and other materials essential for urban existence. Waters used nonconsumptively contribute pollutants to the natural water resources, but this is only one aspect of the grand problem of waste disposal in urban areas, whether on the land, in the ground, in the air, in lakes or streams, or in the sea. Generally in urban areas the responsibilities for water supply and for disposal of "used" water have become public responsibilities.

Urbanization causes some drastic changes in the natural hydrologic system. Buildings and pavements inhibit ground-water recharge and promote rapid runoff from storms. Increased flood peaks cause erosion and sediment transport, as do various construction activities. Vulnerability to floods is increased by urban encroachment upon floodplains. In these and many other ways water causes inconvenience or annoyance to urban life and damage to property and thus constitutes a nuisance. However, the natural environment has been modified so thoroughly that placing responsibility for specific nuisances is difficult.

Urbanization also changes the hydrology of an area profoundly-notably in total runoff, in peak flow characteristics, in the quality of water, and in the appearance of lakes, stream valleys, and other features. To predict, ameliorate, or otherwise cope with these changes, there is urgent need for additional research in urban hydrology and for adequate data to document these changes.

Water can no longer be taken for granted as a readily available urban commodity that can be had at the turn of a faucet. One must give thought to the questions being asked by planners and others who will be responsible for the future of our cities. Today, planners are asking questions that require a new look at water problems in cities and suburbs. They are rapidly becoming aware that decisions for today based upon expediency may result in problems for tomorrow that may be costly or even impossible to solve.

The situation, however, is not entirely bleak. Even today there is a wealth of information on our water resources that can be applied to immediate planning problems. But this is not enough for the future. We need a new look at urban water problems and this row look must be an overall look. Our urban water problem, serious as it is today, is not a separate problem. It is indeed part of our ever-growing national water problem. In this day of competing uses for water, our agriculture, our industry, and we of the general public all strive to meet our individual needs. The urban water problem can be solved, but only if a complete understanding of the role of water in the urban environmentand indeed in the overall water picture-is realized. Such understanding can be achieved through the proper interpretation of adequate data; when we have the understanding, we can make sound decisions.

\section{REFERENCES}

Anderson, P. W., and McCall, J. E., 1968. Urbanization's effect on sediment yield in New Jersey: Jour. Soil and Water Conserv., v. 23, p. 142-144.

Dobrovolny, Ernest, and Schmoll, H. R., 1968, Geology as applied to urban planning: Interrat. Geol. Cong., 23d, Prague, 1968, Proc., v. 12, p. 39-56.

Durfor, C. N., and Becker, Edith, 1964, Public water supplies of the 100 largest cities in the United States: U.S. Geol. Survey Water-Supply Paper $1812,364 \mathrm{p}$.

Kellaway, G. A., and Taylor, J. H., 196ई. The influence of landslipping on the development of the city of Bath, England: Internat. Geo. Cong., 23d, Prague, 1968, Proc., v. 12, p. 65-76.

Leopold, L. B., 1968, Hydrology for urban land planning -a guide book on the hydrologic effects of urban land use: U.S. Geol. Survey Circulay 554, 18 p.

Lusczynski, N. J., 1952. The recovery of ground water levels in Brooklyn, N.Y., from 1947 to 1950: U.S. Geol. Survey Circular 167, 29 p.

Otton, E. G., Martin, R. O. R., and Durum, W. H., 1964, Water resources of the Baltimore area, Maryland: U.S. Geol. Survey Water-Supply Paper 1499-F, $105 \mathrm{p}$.

Perlmutter, N. M., Lieber, Maxim, ard Frauenthal, H. L., 1964, Contamination of grcind water by detergent in a suburban enviroment--South Farmingdale area, Long Island, New Yor' in Geological Survey research 1964. U.S. Geol. Survey. Prof. Paper 501-C, p. C170-C175.

Piper, A. M., 1965, Has the United States enough water?: U.S. Geol. Survey Water-Supply Paper 1797, 27 p. [1966].

Rantz, S. E., 1970, Urban sprawl and flonding in southərn California: U.S. Geol. Survey Circular 601-B, 12 p. (In press.)

Sylvester, R. O., 1960, An engineering and ecological study for the rehabilitation of Greer Lake: Washington University, Seattle. 
U.S. Department of Interior, 1968, The Nation's river: A report on the Potomac: Washington, D.C., $128 \mathrm{p}$.

[U.S.] Water Resources Council, 1968, The Nation's water resources; the first national assessment: Washington, U.S. Govt. Printing Office.

Vice, R. B., Guy, H. P., and Ferguson, G. E., 1969, Sediment movement in an area of suburban highway construction, Scott Run basin, Fairfax County, Virginia, 1961-64: U.S. Geol. Survey Water-Supply Paper 1591-E, 41 p.

Wolman, M. G., 1964, Problems posed by con`truction activities in Maryland: Report to the I aryland Pollution Control Commission, Annapolis, Md.

\U.S. GOVERNMENT PRINTING OFFICE : 1972 0-468-018 
